\title{
Analysis of the Open Space of Prefab Housing Estates in Brno
}

\author{
Analýza volných prostorů brněnských \\ panelových sídlišt'
}

Šárka Kubínová

Ústav urbanismu, Fakulta architektury, Vysoké učení technické v Brně, Česká republika xakubinova@stud.fa.vutbr.cz

\begin{abstract}
The article discusses the itemized dissertation on the "open space of prefab housing estates in Brno". The aim of the thesis is to analyse and describe the unused premises of panel house estates in Brno, and to create and assess a usable system of data and information (regarding chronological sequence). The obtained data and the entire dissertation can be used in planning and designing interventions in prefab housing estates and in other structures of residential areas, or as part of a multi-criteria analysis of the particular housing estates.
\end{abstract}

KEYWORDS: sustainable urban development; open spaces parameters; importance for sustainable development; contemporary urban structures; prefab housing estates; housing

ABSTRAKT: Článek pojednává o rozepsané disertační práci na téma „volný prostor brněnských panelových sídlišst“. Cílem této práce je analyzovat a zmapovat volné prostory na brněnských panelových sídlištích a vytvořit a zhodnotit využitelný systém dat a informací (s ohledem na časovou posloupnost). Získaná data a celou disertační práci bude možné využít při plánování a projektování zásahů na panelových sídlištích i zásahů do struktury jiných obytných celků, popř. jako součást multikriteriální analýzy jednotlivých sídlišst.

KLÍČOVÁ SLOVA: panelová sídliště; urbanistická struktura; parametry volného prostoru; trvale udržitelný urbánní rozvoj; veřejný prostor 


\section{Úvod}

Odhady hovoří o tom, že v dnešní době žije na panelových sídlištích asi třetina obyvatel České republiky. (1) Typizace výstavby vygenerovala časový prostor na výzkum ideální typologie bytové jednotky. Díky tomuto faktu jsou byty v panelových domech typologicky funkční a kvalitní. Panelová sídliště jsou dědictvím dob minulých, vypovídají o ekonomické a hlavně sociopolitické situaci, kterou s sebou v našem prostředí minulý režim přinesl. Jsou součástí životního prostředí mnoha lidí, a proto je třeba věnovat jim patřičnou pozornost. Dizertační práce bude zaměřena na brněnská panelová sídliště a jejich volný prostor.

Urbánní prostředí lze obecně označit za strukturu kombinující zastavěný a nezastavěný prostor. Urbanistická struktura panelových sídlišt se zásadně liší od struktury tradičního rostlého města. Většinu plochy obytných souborů zaujímá na těchto sídlištích volný prostor. Tento převažující volný prostor mezi objekty hraje významnou roli v dalším vývoji panelových sídlišt', a je tak zásadním nástrojem jejich udržitelného rozvoje.

\section{Teoretická východiska a hypotéza výzkumu}

Volný prostor je nedílnou součástí městských struktur již od počátku urbanizace. Jeho parametry a podoba vycházely z každodenních potřeb jeho uživatelů. Volné prostory můžeme dělit $\mathrm{z}$ hlediska vlastnictví či přistupnosti na veřejné, soukromé a poloveřejné. Volný prostor může mít plno různých funkcí. V historických rostlých městech se volný veřejný prostor vytvářel přirozeně jako bezprostřední výsledek potřeb. Veřejné prostory mívaly funkce dopravní (ulice a nábřeží), funkce obchodní (náměstí a tržiště) a funkce relaxační (nábřeží, parky a vnitrobloky).

Na panelových sídlištích se poprvé v historii urbanizace setkáváme s množstvím volného veřejného prostoru, který není určen ke konkrétní funkci. Rozvolněnost zástavby byla způsobem, jak dosáhnout požadované hygienické kvality bydlení - z hlediska proslunění, denního osvětlení a provětrání. V původní myšlence zahradního města měly všechny volné prostory sloužit $\mathrm{k}$ odpočinku a relaxaci a panelová sídliště měla být klidným bydlením v zeleni. Snaha přeměnit kvantitu na kvalitu prostřednictvím opakování se ukázala nefunkční. (2) Architekt Gebrian tvrdí, že analýza úspěšných veřejných prostorů ukazuje jejich malý podíl a velikost v poměru k celkovému objemu zástavby. Ukazuje se tedy, že čím je veřejný prostor menší a čím méně prostř̌edků potřebujeme na jeho údržbu, tím má větší potenciál být kvalitní. (3)

Na jednom z největších brněnských sídlišt - na sídlišti Bohunice - činí zastavěná plo- 
cha asi 18 ha a plocha volného prostoru cca 155 ha. (4) Zastavěná plocha tedy tvoří asi $10 \%$ plochy celého sídliště a zbytek je volný prostor. V tradiční rostlé struktuře města může být tento poměr téměř obrácený.

„Základním teoretickým východiskem práce je hypotéza, že udržitelný urbánní rozvoj je významně ovlivňován charakterem volného prostoru. Konkrétní parametry či charakteristiky takovýchto prostorů mají vliv na vlastnosti a kvality městského prostředí a života $v$ něm. Specifické sociální, environmentální a ekonomické parametry (charakteristiky) prostorů mohou př́mo souviset s udržitelností urbánního rozvoje." (5)

\section{Současný stav řešené problematiky}

\section{Vznik}

Panelová sídliště začala vznikat po druhé světové válce na základě poptávky po bydlení ve městech, kterou bylo třeba rychle uspokojit. Akutní bytová krize po druhé světové válce byla způsobena poničením bytového fondu válkou, pokračujícím procesem urbanizace a zvyšováním nároků na bytový fond. (6) V západních zemích se tato výstavba stala spíše významným krátkodobým experimentem, a tyto země se tak na přelomu 60. a 70. let pomalu navracely $\mathrm{k}$ formám tradičního města a panelová sídliště přestavovaly. V zemích bývalého východního bloku ale sídliště vyhovovala socialistické ideologii, a proto se stala naprosto majoritní formou bytové výstavby.

Vrchol výstavby panelových sídlišt můžeme datovat do 70. a 80. let, kdy byla vystavěna naprostá většina panelových domů. (7) Podle sociologa Musila jsou tato sídliště „Zvláštní typ městských útvarů, jakýsi kř́íženec industrialismu, vulgarizovaného pojetí moderního urbanismu, socialistických představ o kultuře a nedostatečných finančních zdrojü.“ (8) V brněnském prostředí pocházejí z této doby např́íklad sídliště Líšeň a Bohunice, jejichž urbanistickou podobu komentuje Karel Kuče slovy: „Tato sídliště jsou odstrašujicím dokladem absolutního diktátu socialistického zprůmyslněného stavebnictví a dokonání téměr orwellovské vize obytného prostředi." (9)

\section{Společenské změny}

Po změně režimu se na sídliště snesla vlna kritiky. Panelové domy byly odsouzeny jako nedílná součást produktů socialismu. V těchto souvislostech začaly v 90. letech vznikat projekty tzv. humanizace sídlišt'. (10) Tyto projekty však velmi často postrádaly potřebnou koncepčnost a zabývaly se pouze aplikací sedlových a mansardových střech a zbarvení fasád domů. $\mathrm{V}$ posledních letech probíhaly dva vládní dotační programy podporující rekonstrukce panelových objektů. Jednalo se o program Zelená úsporám (11) a program Nový panel (12). 
I když byla panelovým domům přisuzována krátká morální i technická životnost, v současné době zájem o bydlení v panelových domech na brněnských sídlištích neklesá. Mnoho českých panelových sídlišt’ se může pyšnit kvalitami, jako jsou množství a dobrý stav zeleně, dostupnost občanské vybavenosti a již zmíněná typologická kvalita bytů, a proto jsou pro velké množství Čechů žádanou adresou.

\section{Budoucnost}

V současné době musíme řešit otázky budoucnosti panelových sídlišt nejen z hlediska jejich technického stavu a úrovně komfortu jednotlivých bytů, ale také z hlediska jejich urbanistické struktury a kvality volného prostoru. Po stránce udržitelnosti sídlišt budoucnosti je důležité, aby mohly tyto byty konkurovat současným bytům ze všech těchto hledisek. Pohodlí, komfort, ale také ekonomika provozu a ekologická udržitelnost jsou významnými součástmi problému, kterým se musíme zabývat.

\section{Popis úkolu}

U všech brněnských panelových sídlišt bude provedena podrobná analýza volných prostorů. Budou u nich sledovány parametry sídliště jako velikost volné a zastavěné plochy, poměr ploch v soukromém, polosoukromém a ve veřejném vlastnictví, plošné zastoupení jednotlivých funkcí ve volném prostoru, počty obyvatel a uživatelů na plochu volného prostoru, náklady na údržbu, způsob financování aj.

Kromě celků panelových sídlišt budou vybrány i některé př́iklady obytných celků jiných urbanistických struktur (např. bloková zástavba klasického rostlého historického města), aby bylo možné porovnat volný prostor těchto urbanistických struktur a struktur panelových sídlište

Některé konkrétní vybrané volné prostory budou podrobeny důkladnější analýze dle metodiky zpracované Dr. Kopáčikem pro projekt GAČR 15-05237S - Význam volných prostorů pro udržitelný urbánní rozvoj. (13) Budou detailně zkoumány jejich parametry a vliv těchto parametrů na udržitelnost volného prostoru ve všech třech pilírích udržitelnosti.

Úkolem dizertační práce tedy bude vytvořit ucelenou analýzu volných prostorů na panelových sídlištích, která poslouží jako podklad pro hledání nových způsobů využití volného prostoru na panelových sídlištích v Brně.

\section{Použité metody - využití príípadových studií}

V rámci záměru budou využity dva typy případových studií. Prvním typem budou 
ty, jejichž předmětem je celý obytný soubor panelového sídliště, který bude podroben analýze. Jednotlivé př́padové studie budou řazeny chronologicky se zařazením do historického a sociopolitického vývojového kontextu.

U některých sídlišt bude vybrán druhý typ případových studií. Zde se bude jednat o konkrétně vymezené veřejné prostory, na které bude aplikována metodika Dr. Kopáčika pro projekt GAČR 15-05237S.

\section{Závěr}

Českým sídlištím stále hrozí, že půjdou pomalými krůčky ve stopách panelových sídlišt západních zemí, že se z nich pomalu stanou poloprázdná ghetta s problematickou sociální strukturou.

$\mathrm{V}$ posledních letech se výrazně mění pohled na veřejný prostor ve městech. V České republice můžeme vidět stále stoupající zájem o veřejný prostor, zájem veřejný prostor užívat. Ve městě Brně to můžeme vidět v každodenním životě ve veřejném prostoru, na ulicích, náměstích i v parcích.

Pokud mají panelová sídliště být kvalitním prostředím pro život a pokud mají být sociálně, environmentálně i ekonomicky udržitelná, je třeba hledat nástroje, které tento požadavek zajistí. Prvním krokem při hledání těchto nástrojů musí být analýza a identifikace parametrů objektů i volných prostorů na panelových sídlištích, a to zejména těch, které mají zásadní vliv na trvale udržitelný rozvoj těchto sídlišté.

\section{Poznámky}

1. Český statický úřad. 2011. Sčítání lidu, domů a bytů. [Online] 2011. [Citace: 10. 07 2016.] https://vdb.czso.cz/vdbvo2/faces/cs/index.jsf?page=vystup-objekt-vyhledavani\&evo=_!_SP--352-H_1\&pvo=SPCR352\&pvokc=\&katalog=all\&vyhltext $=$ panel\& $\mathrm{z}=\mathrm{T} \# \mathrm{w}=$.

2. Koolhaas, Rem. SMLXL, What Ever Happened to Urbanism. New York: The Monacelli Press, 1995. ISBN 1-885254-86-5.

3. Gebrian, Adam. Veřejný, nebo zbytkový prostor? Era 21. 2009, 2, stránky 12-21.

4. Pecka, Lukáš. Brněnská sídliště a jejich urbanistická struktura. Brno : Vysoké učení technické v Brně, Fakulta architektury, 2013. Dizertační práce.

5. Wittmann, Maxmilián a Kubínová, Šárka. Vliv volných prostorů na udržitelný rozvoj měst - teoretické souvislosti výzkumu, problematika panelových sídlišté. Životné prostredie. 2015, 49, 2, stránky 87-93. 
6. Špaček, Ondřej a Maier, Karel. Česká panelová sídliště: faktory stability a budoucího vývoje. Sociologický časopis. 2012, 5, stránky 965-988.

7. ibidem

8. Horská, Pavla, Maur, Eduard a Musil, Jiří. 2002. Zrod velkoměsta : urbanizace českých zemí a Evropa. Praha : Paseka, 2002. ISBN 80-7185-409-3.

9. Kuča, Karel. 2000. Brno - vývoj města, předměstí a připojených vesnic. Brno : Baset, 2000.

10. Aulická, Zdeňka a kol. Regenerace sídlišt. Praha : Výzkumný ústav výstavby a architektury, 1993. ISBN: 80-85124-25-4.

11. Ministerstvo pro místní rozvoj, Státní fond rozvoje bydlení. Nový panel+, Nařízení vlády 468/2012 Sb. o použití prostředků Státního fondu rozvoje bydlení formou úvěrů poskytnutých právnickým a fyzickým osobám na opravy a modernizace domů. Státní fond rozvoje bydlení. [Online] [Citace: 11.07.2016.] http:// www.sfrb.cz/fileadmin/sfrb/docs/programy/Uvery_na_opravy_a_modernizace_domu/Narizeni_vlady_468-2012_Sb._platne_od_8.8.2014.pdf.

12. Ministerstvo životního prostředí, Státní fond životního prostředí ČR. Zelená úsporám. [Online] [Citace: 11.07 2016.] http://www.zelenausporam.cz/sekce/470/popis-programu/.

13. Kopáčik, Gabriel: Vliv volných prostorů na udržitelný urbánní rozvoj. Charakteristiky, indikátory a způsob hodnocení ve třech pilírích udržitelnosti. Pracovní materiál projektu GAČR 15-05237S. Brno: VUT v Brně, Fakluta architektury, 2015, ms.

\section{Prameny}

Koryčánek, Rostislav a další. Postavit domy nestačí, Vizuální kultura a veřejný prostor města Brna v období po druhé světové válce. Brno : Vysoké učení technické v Brně, Fakulta výtvarných umění, 2016, ISBN: 978-80-214-5301- 2

Maier, Karel. Sídliště: problém a multikriteriální analýza jako součást přípravy k jeho řešení. Sociologický časopis. 2003, 5.

Moravčíková, Henrieta. Bratislava: atlas sídlisk 1950 - 1995. Bratislava : SLOVART, 2012. ISBN 978-80-556-0478-7.

Musil, Jiří a kol. Lidé a sídliště. Praha : autor neznámý, 1985.

Tichý, D. a další. Sídliště jak dál? Praha : Zlatý řez, 2016. ISBN 978-80-01-05905-0. 